\title{
MIGRAÇÕES NO MERCOSUL
}

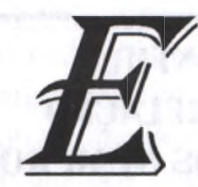

m 1991 foi assinado, entre Brasil, Argentina, Uruguai e Paraguai, o Tratado de Assunção visando a constituição de um Mercado Comum - o Mercosul. Se é verdade que no campo das transações comerciais os valores envolvidos sofreram considerável incremento, passando de 4 bilhões de dólares em 1991 para 14 bilhões de dólares em 1996, no campo das migrações não se pode dizer o mesmo. Ou seja, a constituição do Mercosul não deflagrou, até o momento, novos fatos significativos em termos de deslocamentos populacionais. Todavia, a migração no âmbito do Mercosul é uma realidade e sobre ela falamos aqui.

Diferentemente do que ocorre com os brasileiros que emigram para os países do chamado Primeiro Mundo - em direção ao mercado urbano - a emigração do Brasil para os paises do Mercosul apresenta um caráter fundamentalmente rural. Haesbaert e Silveira discorrem sobre esse processo e, juntamente com Sprandel, que busca averiguar como se dá a "livre circulação de forças produtivas", uma das prerrogativas do Tratado, concluem que para os migrantes os efeitos da integração pairam distantes. $O$ mesmo afirma Silva a partir do estudo do fenômeno inverso - a presença dos hispanoamericanos na cidade de São Paulo.

Sob outro ângulo - o religioso - e em outras proporçôes, Oro e Carozzi trazem à tona a penetração de cultos afro-brasileiros e pentecostais em direção aos países Platinos, bem como as transformações sofridas a partir do novo contexto.

Vilallón focaliza as Politicas Imigratórias na Argentina deixando claro que as leis sempre se pautaram pela dubiedade: de um lado acenam favoravelmente ao ingresso de estrangeiros e, de outro, impóem claras restriçôes, sobretudo as migrações limitrofes. Ou seja, o ingresso é facilitado apenas a quem o Estado julgar conveniente.

Não foi, pois, a constituição de um Mercado Comum que conduziu a uma maior integração no caso das migrações, aliás, a integração vista sob este ângulo apresentase minada de contradições. Uma contradição?... Gonçalves traça uma análise do que vem ocorrendo no campo da agricultura brasileira a partir da globalização e da integração do Brasil no Mercosul e deixa evidente de que o principio básico continua sendo a guerra do "quem pode mais, chora menos". Dá exemplo, inclusive, de transaçôes comerciais envolvendo Brasil, Argentina e Estados Unidos que, a partir da ótica da integração, soariam como brincadeiras de criança e de mau gosto. Todavia, não são brincadeiras de criança, são lances de um mercado adulto, moderno, que possibilitam entender um pouco o que por vezes parece chucra contradição.

$$
\text { Dirceu Cutti }
$$

